\title{
Chemopreventive Effect of Brazilian Green Propolis on Experimental Dermal Carcinogenesis in Murine Model
}

\author{
Efecto Quimiopreventivo del Propóleos Verde Brasileño sobre la \\ Carcinogénesis Cutánea en el Modelo Murino Experimental
}

\begin{abstract}
Rose Nely Pereira-Filho*; Fellipe Santos Batista**; Danielle Rodrigues Ribeiro*; Genecy Calado de Melo**; Francisco Prado Reis"; Allan Ulisses Carvalho de Melo**; Margarete Zanardo Gomes*; Juliana Cordeiro Cardoso* \& Ricardo Luiz Cavalcanti de Albuquerque Júnior*,**
\end{abstract}

PEREIRA-FILHO, R. N.; BATISTA, F. S.; RIBEIRO, D. R.; MELO, G. C.; REIS, F. P.; MELO, A. U. C.; GOMES, M. Z.; CARDOSO, J. C. \& ALBUQUERQUE-JÚNIOR, R. L. C. Chemopreventive effect of Brazilian green propolis on experimental dermal carcinogenesis in murine model. Int. J. Morphol., 32(2):522-530, 2014.

SUMMARY: The aim of this study was to assess the effect of oral administration of Hydroalcoholic Extract of Green Propolis (HEGP) on dermal carcinogenesis in rodent model. For the biological assay, we used 36 mice, assigned into 6 groups (n=6): CTR (treated with $100 \mathrm{mg} / \mathrm{kg} \mathrm{HEGP}$ and no tumor induction), TUM (treated with water and tumor induction), GP10 (treated with $10 \mathrm{mg} / \mathrm{kg}$ HEGP and tumor induction), GP50 (treated with $50 \mathrm{mg} / \mathrm{kg}$ HEGP and tumor induction) and GP100 (treated with $100 \mathrm{mg} / \mathrm{kg}$ HEGP and tumor induction). Cancer induction was performed in the back of the mice by topical application of DMBA. After 16 weeks, mice were euthanized and their backs were submitted to post-mortem histological analysis. The mean number of lesions developed in TUM (4.14 \pm 0.89$)$ was significantly higher than in GP10 (2.05 \pm 1.02$)$, GP50 (1.8 \pm 1.92$)$ and GP100 $(2.5 \pm 1.73)(\mathrm{p}<0.05)$. The tumors formed in HEGPtreated groups were histologically more differentiated, but only in PV100 in situ lesions were evidenced. Infiltration of anatomical noble structures was less frequent in HEGP-treated groups $(\mathrm{p}<0.05)$. Our data suggest that oral administration of HEGP provided partial inhibition of DMBA-induced dermal carcinogenesis, as well as appeared to modulate the differentiation and infiltrative potential of the carcinomas in rodent model.

KEY WORDS: DMBA; Propolis; Skin cancer.

\section{INTRODUCTION}

Propolis is a complex resinous hive substance originated from a mixture of plant resins and salivary enzymes of bees. It is collected by honeybees from various plant sources. Botanical origin and chemical composition of Brazilian propolis has already been made and it was noted that, depending on the region, and even on the season, there are some differences between distinct types of propolis (Sawaya et al., 2011).

The chemical composition of propolis is made up of more than 200 substances including flavonoids, amino acids, vitamins, artepilin $\mathrm{C}$, quercetin, naringenin, resveratrol, galangin, genistein polyphenolic compounds as caffeic acid (CA) and caffeic acid phenethyl ester (CAPE); caffeoylquinic and prenylated cinnamic acids, such as artepillin $\mathrm{C}$ and baccharin (Orsolic et al., 2005, 2006).
Propolis has been used since ancient times as a folk medicine for the treatment of many diseases. Numerous biological and pharmacological properties of propolis, including antitumoral, have been reported in the last decades (Araujo et al., 2012).

Chemoprevention is the area of oncology which focuses on prevention of cancer using natural or synthetic agents. In addition to inhibiting or delaying the onset of neoplasia by blocking neoplastic inception, chemoprevention plays a role in preventing the development of invasive and metastatic properties in established neoplasm (Szliszka $e t$ al., 2009).

Non melanoma skin cancers (NMSCs) represent the most common cancers in several countries. Basal cell carcinoma (BCC) and squamous cell carcinoma (SCC) are the

\footnotetext{
* Science and Technology Institute, University Tiradentes, Brazil.

** School of Dentistry, University Tiradentes, Brazil.
} 
PEREIRA-FILHO, R. N.; BATISTA, F. S.; RIBEIRO, D. R.; MELO, G. C.; REIS, F. P.; MELO, A. U. C.; GOMES, M. Z.; CARDOSE, J. C. \& ALBUQUERQUE-JÚNIOR, R. L. C. Chemopreventive effect of Brazilian green propolis on experimental dermal carcinogenesis in murine model. Int. J. Morphol., 32(2):522-530, 2014.

most common histopathological variants (Kim \& Armstrong, 2012). Among the new therapeutic anti-cancer compounds, the potential of natural products has been investigated. In vivo and in vitro researches using extracts of native plants from Brazil have shown good results (Cragg et al., 2009; Ozi et al., 2011). Recently, it was demonstrated that hydroalcoholic extract of green propolis plays an important protective role against chemically-induced lingual carcinogenesis in rats (Cavalcante et al., 2011).

Therefore, the aim of this study was to assess the effect of oral administration of hydroalcoholic extract of Brazilian green propolis (HEGP) on dermal carcinogenesis in rodent model.

\section{MATERIAL AND METHOD}

Ethical perspectives. Ethical principles of the COBEA (Brazilian College for Animal Experimentation) for experiments in animals were applied in this study. This study was approved by the Ethics Committee of the Tiradentes University (CEUA/UNIT No. 090911).

Gathering propolis and obtaining a propolis extract. Propolis was gathered from apiaries in the Southeast region (Montes Claros, 16 44' 06" S 43 51' 43"). The material was labeled and placed in sterile refrigerated containers and sent to the laboratory. The extract was obtained by using Maia-Araújo's method. One gram of each sample of propolis was placed in a sterile test tube with $12.5 \mathrm{~mL}$ of a $70 \%$ ethanol and then taken to the ultrasound machine to extract for 1 hour. The extracts were centrifuged at $3000 \mathrm{rpm}$ for 15 minutes and the supernatants were left in laminar flow for complete evaporation of the solvent and mass obtaining. The resulting powder was stored in a sterile test tube with screw cap and stored refrigerated. The extraction yield relative to the initial mass of propolis was calculated and expressed as a percentage.

Determining the concentration of flavonoids. The concentration of total flavonoids was established as described by Adelmann. For this, 15 to $1000 \mathrm{~mL}$ of the extract (concentrations of 5 to $100 \mathrm{mg} / \mathrm{mL}$ ) were added to a solution containing $0.1 \mathrm{~mL}$ of $10 \%$ aluminum nitrate and $0.1 \mathrm{~mL}$ of potassium acetate $(1 \mathrm{~mol} / \mathrm{liter})$. The end volume was completed to $5 \mathrm{~mL}$ with $80 \%$ ethanol. The samples were homogenized and absorbance was measured spectrophotometrically at $415 \mathrm{~nm}$ after 40 minutes at room temperature. Quercetin at 5 to $50 \mathrm{mg} / \mathrm{mL}$ concentrations, dissolved in ethanol, was used to build the standard concentration curve; total flavonoid values were expressed as quercetin equivalents ( $\mathrm{mg}$ of quercetin in $100 \mathrm{mg}$ of total $\mathrm{mL}$ of 9,10 dimethyl 1,2-benzantracene (DMBA, SigmaAldrich, St. Louis, USA) solution. One gram of the carcinogen was diluted in acetone (P.A.) to obtain a $0.5 \%$ solution. The carcinogen was applied twice a week during 16 weeks on the dorsum skin of the mouse after trichotomy with a micropipette. The animals were randomly allocated to five groups $(n=6)$, as demonstrated in Table I. An oral dose of hydroalcoholic extract of green propolis (administered by gavage) was administered to the animals of the groups GP10 (10 mg/kg), GP50 (50 mg/kg), GP100 $(100 \mathrm{mg} / \mathrm{kg})$ and CTR $(100 \mathrm{mg} / \mathrm{kg})$. In addition, $1.0 \mathrm{~mL}$ of distilled water was administered by gavage to animals of the group TUM. DMBA $0.5 \%$ was applied on the dorsum skin of the mice of the groups PV10, PV50, PV100 and TUM. Distilled water was applied in the negative control groups (CTR).

Table I. Distribution of the animals in the experimental groups according to treatment.

\begin{tabular}{lcl}
\hline Groups & Topical application & Oral administration \\
\hline CTR1 & Distilled water & $1 \mathrm{~mL}$ of $2 \%$ tween 80 \\
CTR2 & Distilled wa ter & $100 \mathrm{mg} / \mathrm{Kg}$ HEGP \\
TUM & DMBA a $0.5 \%$ & $1 \mathrm{~mL}$ of $2 \%$ tween 80 \\
GP10 & DMBA a $0.5 \%$ & $10 \mathrm{mg} / \mathrm{Kg}$ HEGP \\
GP50 & DMBA a $0.5 \%$ & $50 \mathrm{mg} / \mathrm{Kg}$ HEGP \\
GP100 & DMBA a $0.5 \%$ & $100 \mathrm{mg} / \mathrm{Kg}$ HEGP \\
\hline
\end{tabular}

Gavage procedures. The dry extract of green propolis was again placed in suspension at $2 \%$ Tween 80 at $10 \mathrm{mg} / \mathrm{mL}$. These substances were administered orally every other day (differing from the days of DMBA application). Gavage was done during one week with the same dosages before inducing carcinogenesis, for 16 weeks, to verify possible adverse reactions to the natural product, as preconized by Kavitha \& Manoharan (2006).

Macroscopic analysis of DMBA-induced lesions. The lesions induced in the animals' skin were classified according to the clinical presentation in ulcerative, verrucous or ulcerative/verrucous. The tumor volume (TV) was assessed according to the equation: $V=4 / 3 . \pi \mathrm{d}$, where $\mathrm{V}=$ volume; $\pi=3.14$ and $\mathrm{d}=$ mean diameter.

The mean index of lesion induction (In) was obtained using the equation: $\mathrm{In}=((\mathrm{nL}) \times(\mathrm{nA}) /(\mathrm{nT})) \times 100$, where: $\mathrm{In}$ $=$ Index of DMBA-induced lesions; $\mathrm{nL}=$ number of lesions observed per animal; $\mathrm{nA}=$ number of animals presenting DMBA-induced lesions and $\mathrm{nT}=$ total number of animals per group.

Histomorphological analysis of DMBA-induced lesions. After 16 weeks, animals were euthanized in a $\mathrm{CO}_{2}$ chamber 
PEREIRA-FILHO, R. N.; BATISTA, F. S.; RIBEIRO, D. R.; MELO, G. C.; REIS, F. P.; MELO, A. U. C.; GOMES, M. Z.; CARDOSO, J. C. \& ALBUQUERQUE-JÚNIOR, R. L. C. Chemopreventive effect of Brazilian green propolis on experimental dermal carcinogenesis in murine model. Int. J. Morphol., 32(2):522-530, 2014.

for post-mortem removal of the treated area, irrespective to the presence or absence of tumors. Tissue specimens were fixed in buffered formaldehyde (10\%, $\mathrm{pH} 7.4)$ for $24 \mathrm{~h}$, dehydrated in increasing ethyl alcohol solutions, and diaphanized in xylol for inclusion in paraffin. Subsequently, $5 \mathrm{~mm}$ thick histological sections were obtained and stained in hematoxylin-eosin for analysis at a light microscope.

Assessment of the histological malignancy grading of the tumors. The diagnosis of the epithelial tumors produced in the animals was carried out according to their histological features, as described by Yanofsky et al. (2011), and the histological malignancy grading was assessed using the criteria established by the guidelines for the diagnosis and treatment of cutaneous squamous cell carcinoma and precursor lesions (Bonerandi et al., 2011). The four broadest classification grades were based on the ratio of differentiated to undifferentiated cells (grade $1=3: 1$, grade $2=1: 1$, grade $3=1: 3$ and grade $4=$ no tendency towards differentiation). When invasion of the hypodermis was noticed, the presence or absence of lymphatic and muscle infiltration was analyzed.

Statistical Analysis. The tumor volume (TV) and index of tumor induction (InT) in the animals of each group were expressed as mean \pm standard error mean, and analyzed by variance analysis and post-hoc Tukey's test. The other data were expressed as values of absolute (n) and relative (\%) frequency, and compared among the groups using the Fisher's exact test. Differences among the groups were considered significant when $\mathrm{p}<0.05$.

\section{RESULTS}

The yield of the dry propolis extract was $44.43 \%$. The green propolis sample contained a $0.95 \pm 0.44 \%$ flavonoids. In the biological assay, no change in the intake of food and water was observed in the experimental groups. The animals presented a slight body weight loss in the four first weeks of the experiment, and then showed a progressive increase until the 16th week (Fig. 1). However, no significant difference was observed among the groups during the time course of the experiment $(\mathrm{p}>0.05)$.

As shown in Figure 2, the DMBA-induced cutaneous tumors presented as multiple ulcerative and exofitic lesions, with erosive and leukoplastic surfaces. Both control groups (CTR1 and CTR2) presented no macroscopic changes in the dermal tissues.

The index of lesion induction (InT) was significantly higher in the TUM group (4.14 \pm 0.89$)$ than in GP10

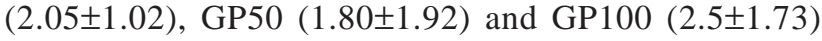
$(\mathrm{p}<0.05)$, but there was no difference between the groups treated with HEGP ( $p>0.05)$ (Fig. 3A). Regarding the mean tumor volume (TV) of chemically induced tumors (Fig. 3B), there was no significant difference between the groups studied, regardless of treatment with HEGP $(p>0.05)$.

All the tumors developed in this study were represented by squamous cell carcinomas, with different grades of cell differentiation. The control groups (CTR1 and CTR2) exhibited no changes in the morphological architecture of the dermal tissues (Fig. 4). As demonstrated in Table II, we found that the majority of the animals of TUM developed less differentiated SCC (grades 3 and 4), whereas the oral administration of HEGP was significantly associated to the formation of better differentiated (grades 1 and 2) $(p=0.043)$, but there was no difference among the HEGP-treated groups $(\mathrm{p}>0.05)$.

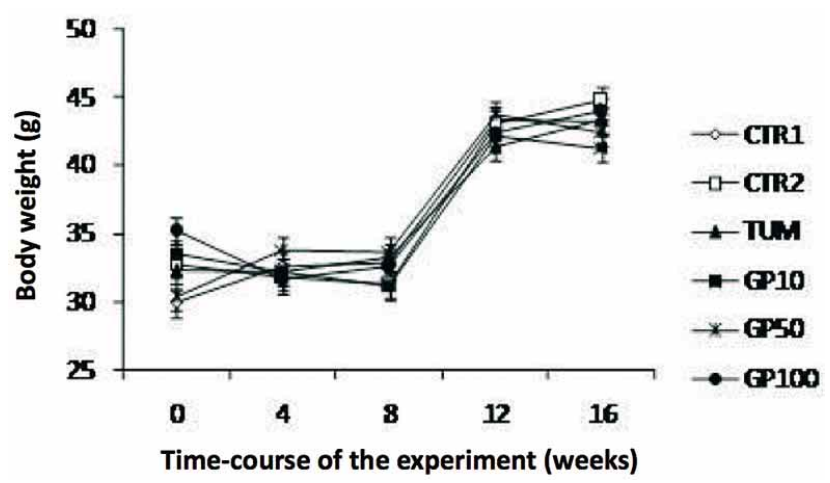

Fig. 1. Assessment of the body weight of animals of the experimental groups over the time-course of the experiment.

Regarding the histological assessment of tumor infiltration on noble structures, it was noticed that in the TUM group, $83.33 \%$ of cases had muscle involvement and $66.66 \%$ had lymphatic invasion by tumor cells (Fig. 5). On the other hand, in the groups treated with HEGP, only one case of group GP50 exhibited muscle and lymphatic invasion $(20 \%)$. This difference in the frequency of tumor infiltration on noble structures was shown to be significant between HEGP-treated and untreated animals $(\mathrm{p}<0.05)$.

The inflammatory response against the neoplastic cells, ranging from mild to intense, was observed in all the DMBA-induced cutaneous tumors. Such immunological reaction was represented by lymphocytic infiltration permeating the islands and sheets of tumor squamous cells (Fig. 6). As demonstrated in the Table III, there was no significant difference in the intensity of the inflammatory response regardless the treatment with HEGP $(\mathrm{p}>0.05)$. 


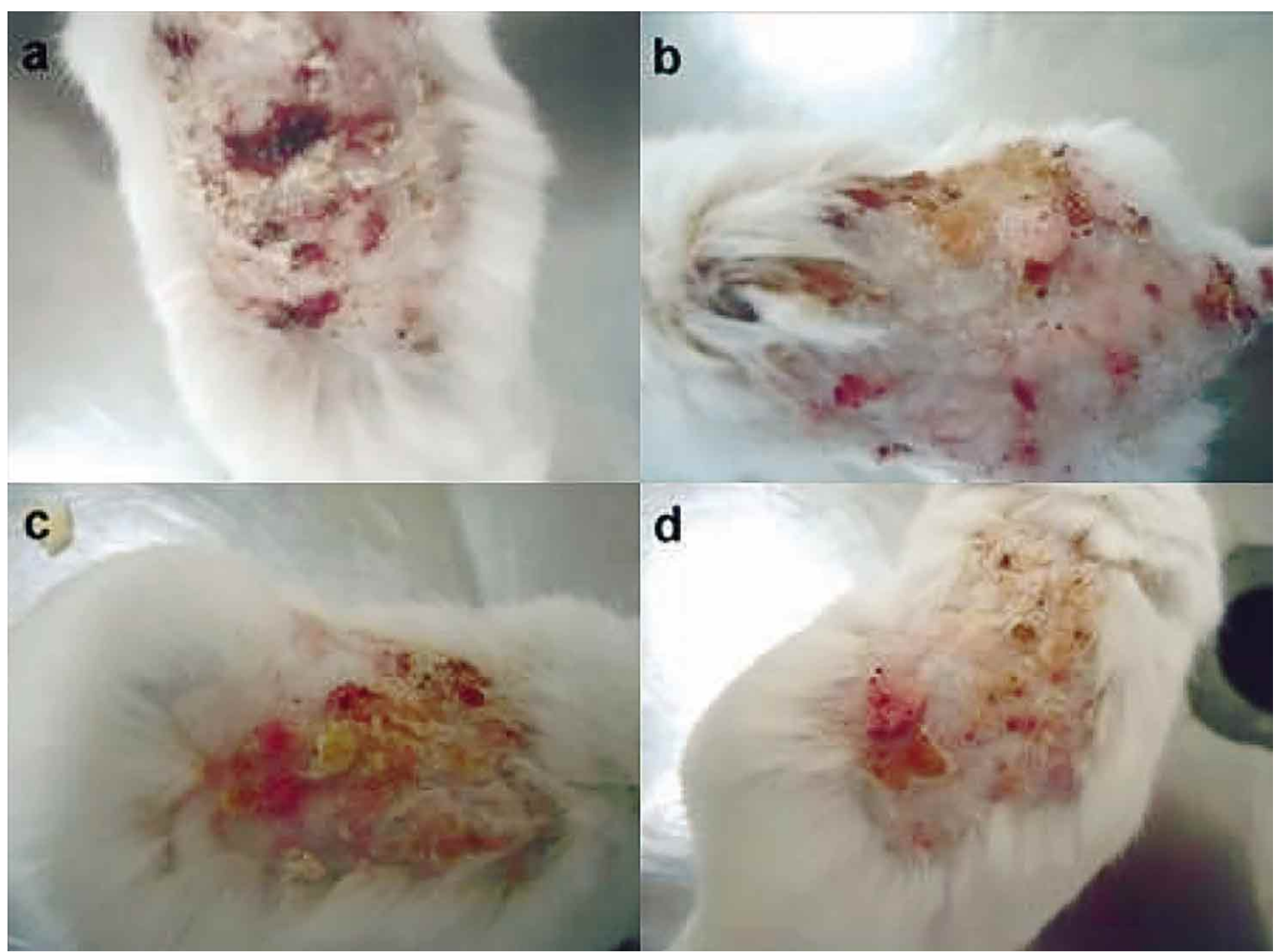

Fig. 2. Clinical appearance of the DMBA-induced cutaneous tumors. (a) TUM, (b) GP10, (C) GP50 and (d) GP100. Note the lower number of lesions in HEGP-treated groups.

(A)

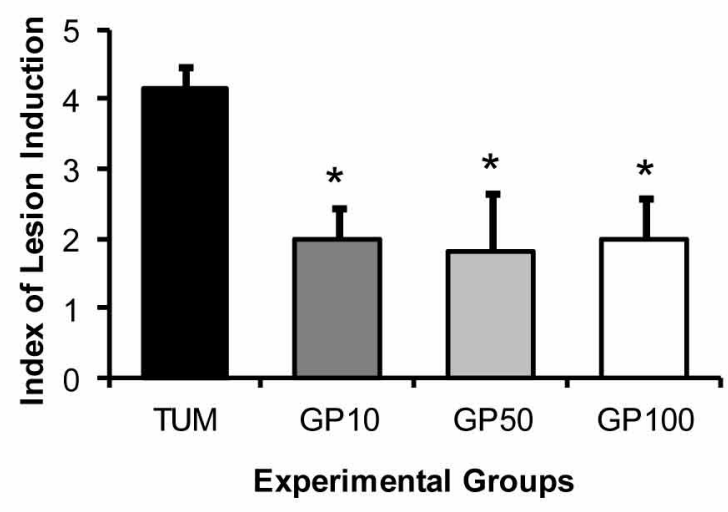

(B)

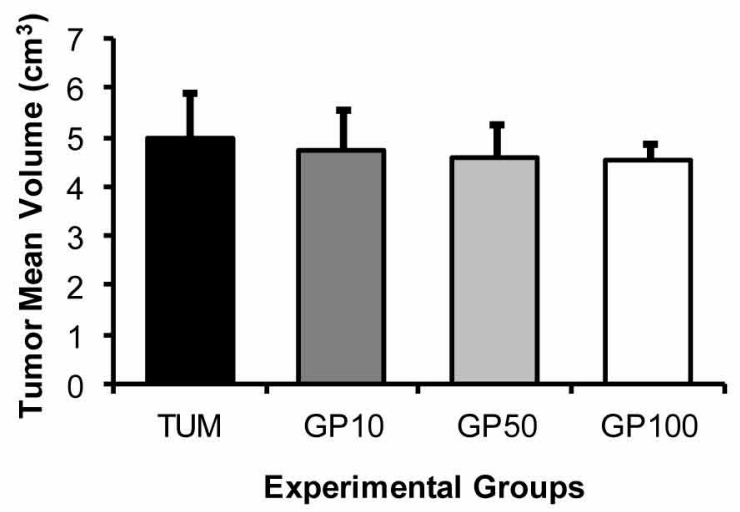

Fig. 3. Macroscopic assessment of the average tumor volume (TV) and index of lesion induction (InT in the experimental groups.

* Significant difference from TUM $(\mathrm{p}<0.05)$. 
PEREIRA-FILHO, R. N.; BATISTA, F. S.; RIBEIRO, D. R.; MELO, G. C.; REIS, F. P.; MELO, A. U. C.; GOMES, M. Z.; CARDOSO, J. C. \& ALBUQUERQUE-JÚNIOR, R. L. C. Chemopreventive effect of Brazilian green propolis on experimental dermal carcinogenesis in murine model. Int. J. Morphol., 32(2):522-530, 2014.

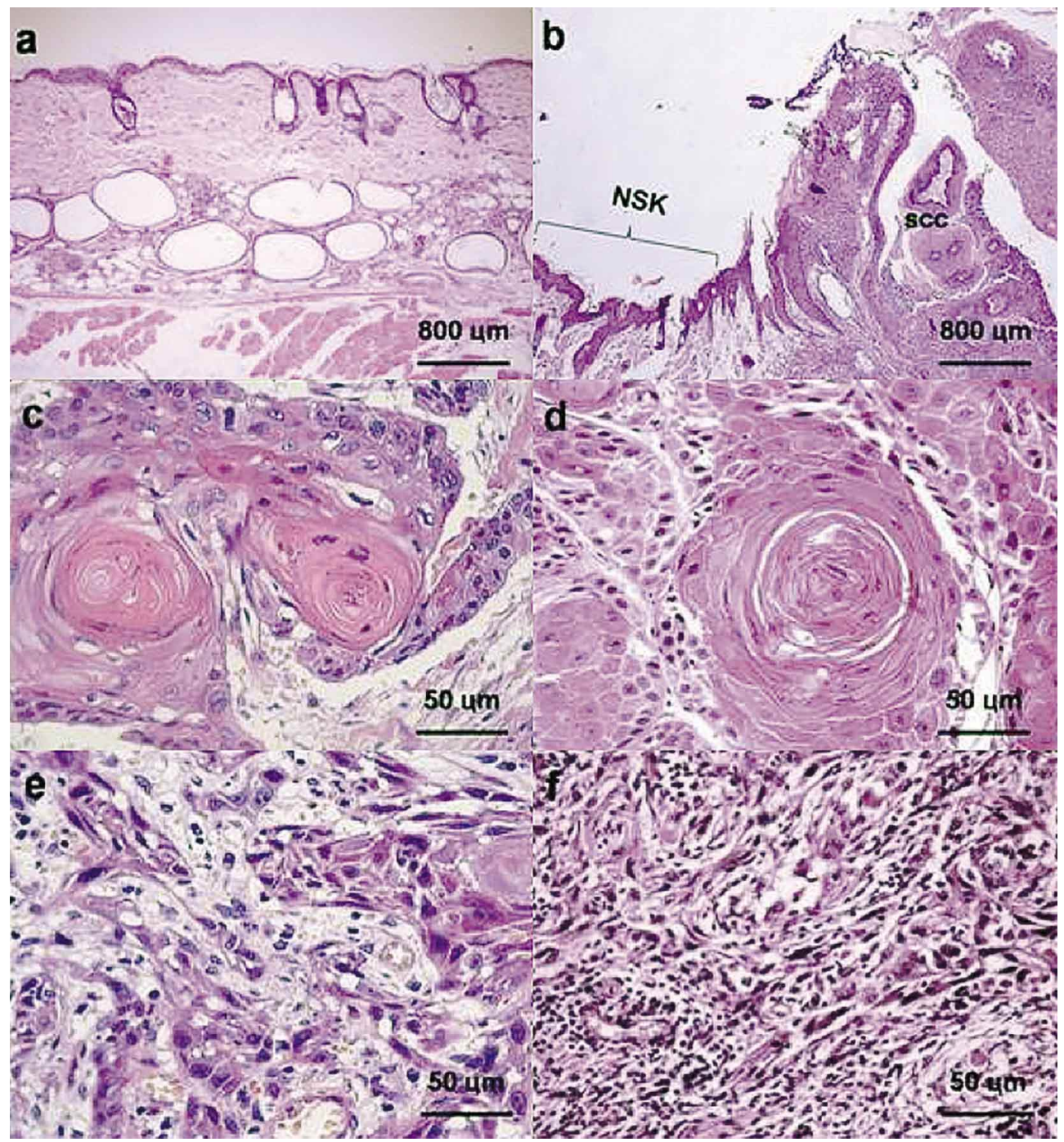

Fig. 4. Histopathological analysis of the dermal tissues. In the control group (a), usual morphological architecture of the dermal tissues are observed, whereas in TUM (b), the squamous cell carcinoma (SCC) is observed arising from the normal skin (NSK). The tumors (carcinomas) presented different malignancy gradings: Grade 1 (c) and 2 (d) represent well-differentiated tumors, whereas grade 3 (e) and 4 (f) are regarded as poorly differentiated carcinomas (HE stain).

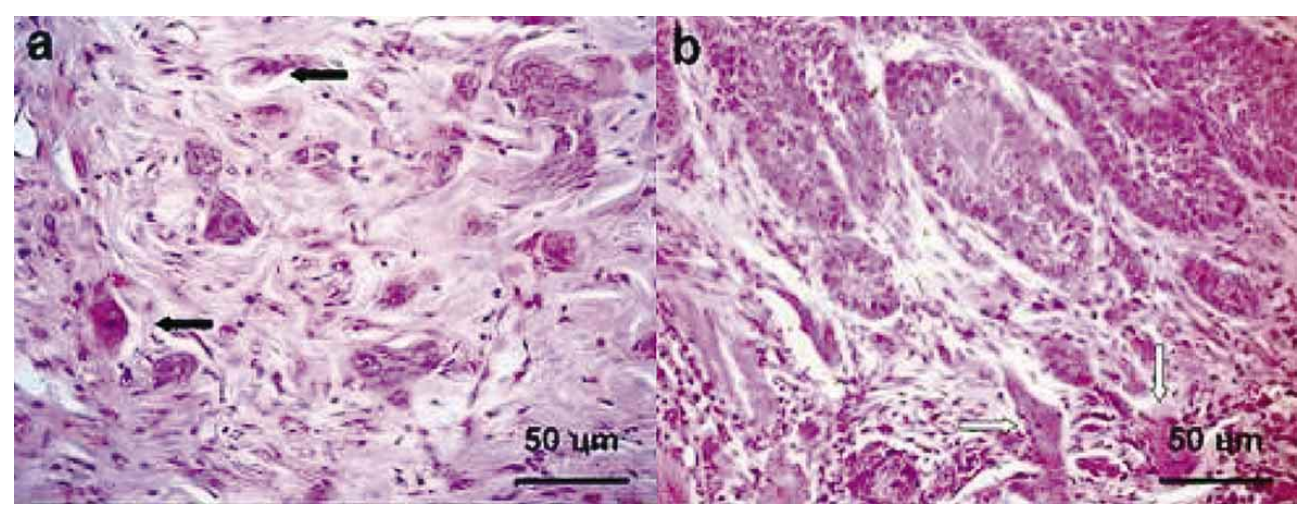

Fig. 5. Histopathological evidence of tumor infiltration of noble structures by neoplastic cells. (a) Neoplastic cells within lymphatic vessels (black arrows). (b) Infiltration and intense dissociation of muscular fibers by neoplastic cells (white arrows) (HE, 400x magnification). 
PEREIRA-FILHO, R. N.; BATISTA, F. S.; RIBEIRO, D. R.; MELO, G. C.; REIS, F. P.; MELO, A. U. C.; GOMES, M. Z.; CARDOSO, J. C. \& ALBUQUERQUE-JÚNIOR, R. L. C. Chemopreventive effect of Brazilian green propolis on experimental dermal carcinogenesis in murine model. Int. J. Morphol., 32(2):522-530, 2014.

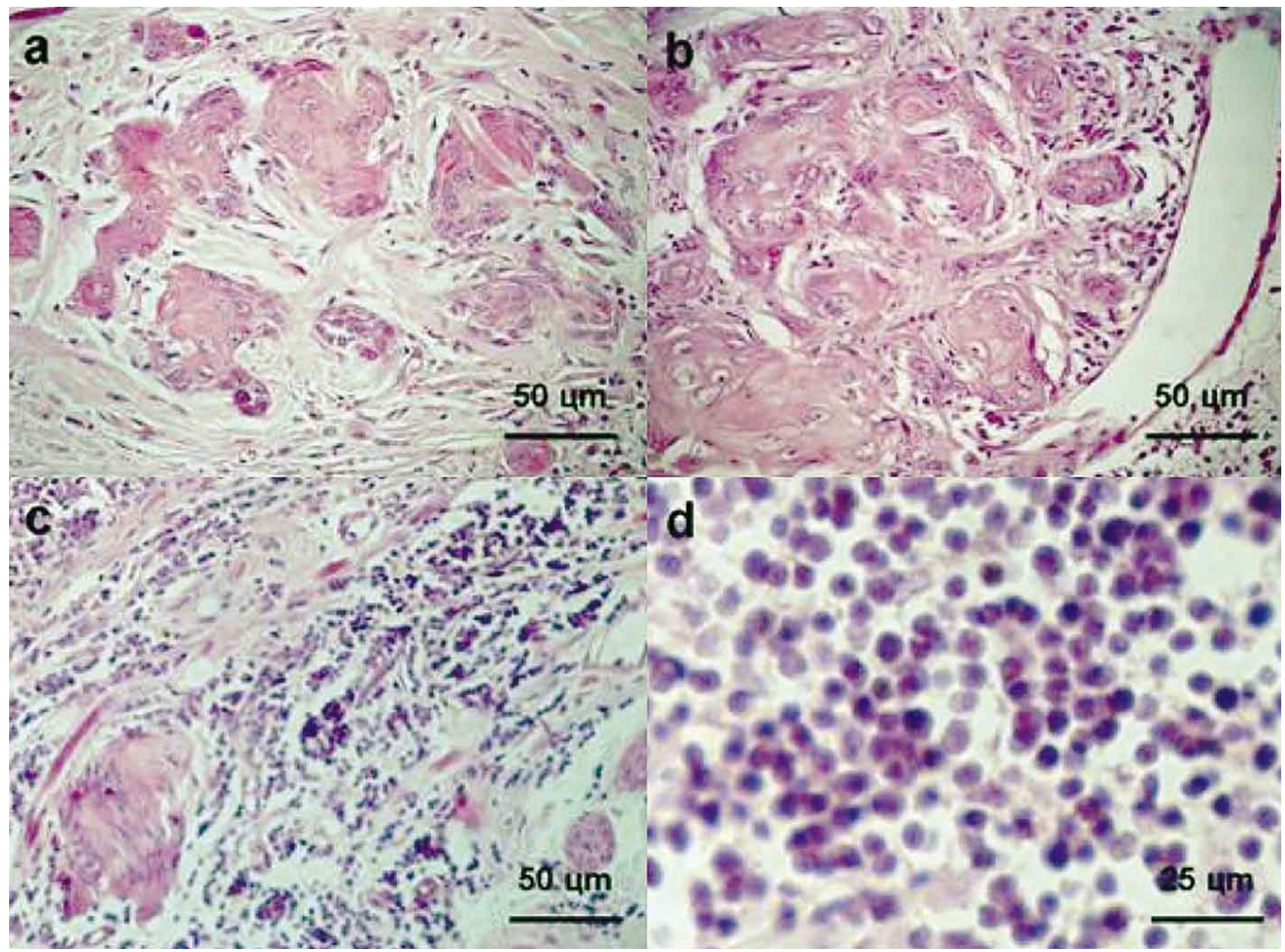

Fig. 6. Histopathological patterns of the inflammatory response to the presence of invasive tumor cells in the dermal tissues. (a) Mild, (b) moderate and (c) intense inflammatory infiltrate, composed of (d) round-shaped leukcoytes consistent with lymphocytes (a/b/c - HE, 400x magnification; $d-800 x$ magnification).

Table II. Histological Malignancy Grading of the DMBA-induced cutaneous squamous cell carcinomas in the experimental groups.

\begin{tabular}{lcccc}
\hline \multirow{2}{*}{$\begin{array}{l}\text { Histological } \\
\text { malignancy grading }\end{array}$} & \multicolumn{4}{c}{ Experimental groups } \\
\cline { 2 - 5 } & TUM & GP10 & GP50 & GP100 \\
\cline { 2 - 5 } & $\mathbf{n}(\boldsymbol{\%})$ & $\mathbf{n}(\boldsymbol{\%})$ & $\mathbf{n}(\boldsymbol{\%})$ & $\mathbf{n}(\boldsymbol{\%})$ \\
\hline Grade 1 & 0 & $3(50)$ & $5(83.33)$ & $4(66.66)$ \\
Grade 2 & $1(16.66)$ & $2(33.33)$ & $1(16.66)$ & $2(33.33)$ \\
Grade 3 & $3(50)$ & $1(16.66)$ & 0 & 0 \\
Grade 4 & $2(33.33)$ & 0 & 0 & 0 \\
\hline
\end{tabular}

Table III. Histological assessment of the intensity of the inflammatory response to the squamous cell carcinomas in the experimental groups.

\begin{tabular}{|c|c|c|c|}
\hline \multirow{3}{*}{ Experimental groups } & \multicolumn{3}{|c|}{ Intensity of the inflammatory response } \\
\hline & Mild & Moderate & Intense \\
\hline & n $(\%)$ & n (\%) & $\mathrm{n}(\%)$ \\
\hline TUM & $3(50.00)$ & $1(16.66)$ & $2(33.33)$ \\
\hline PG10 & $1(16.66)$ & $3(50.00)$ & $2(33.33)$ \\
\hline PG50 & $2(33.33)$ & $3(50.00)$ & $1(16.66)$ \\
\hline PG100 & $1(16.66)$ & $3(50.00)$ & $2(33.33)$ \\
\hline
\end{tabular}


PEREIRA-FILHO, R. N.; BATISTA, F. S.; RIBEIRO, D. R.; MELO, G. C.; REIS, F. P.; MELO, A. U. C.; GOMES, M. Z.; CARDOSO, J. C. \& ALBUQUERQUE-JÚNIOR, R. L. C. Chemopreventive effect of Brazilian green propolis on experimental dermal carcinogenesis in murine model. Int. J. Morphol., 32(2):522-530, 2014.

\section{DISCUSSION}

Carcinogenesis has several stages including initiation, promotion and tumor progression. Research has been made to discover a natural or a synthetic compound that could prevent, slow or reverse the process of carcinogenesis. Propolis has been regarded as one of the most promising products used in chemoprevention (Orsolic et al., 2005).

In this research, oral administration of HEGP induced no significant changes either in the water and food intake of the animals. However, there was a slight body weight loss until the fourth week, although it was reversed over the time. Such loss is likely related to an adaptation period, when higher stress levels are induced in the animals as a result of experimental manipulation. Since no difference was observed among the groups, it is possible to suggest that oral HEGP administration exerted no influence in the pattern of feeding and body weight of the animals.

We demonstrated that oral administration of HEGP promoted inhibition of growth of DMBA-induced epithelial tumors in mice. However, once no difference between HEGP-treated groups, it is suggestive that this effect is not dose-dependent. The antitumor activity of Brazilian propolis has also been proven in other studies (Cavalcante et al.; Franchi et al., 2012).

One hypothesis to explain these results is that the hydroalcoholic extract of green propolis inhibits the synthesis of nitric oxide that facilitates the rapid growth tumor (Araújo et al., 2010). Another explanation is that caffeic acid phenethyl ester (CAPE), a derivative of caffeic acid, and another anticancer ingredient called ARC (artepillin C) inactivates PAK1 which is one of the responsibles for tumor growth (Orsolic et al., 2005; Messerli et al., 2009; Wu et al., 2011).

Other biological mechanisms associated to antitumor activity of propolis extracts have been described. It has been reported that hydroalcoholic extracts of Brazilian green propolis are able to inhibit the angiogenesis process by blocking the ERK1/2 protein-derived anti-apoptotic signalizing in endothelial cells (Kunimasa et al., 2010).

In this study, the mean tumor volume of chemically induced skin lesions was not significantly different between groups. These data suggest that despite having a potential inhibitory effect on tumor induction, administration of HEGP does not affect the rate of growth of epithelial tumors since the promotion/progression phase of carcinogenesis has been triggered.
In this study, the oral administration of HEGP seemed to affect the pattern of tumor differentiation, resulting in welldifferentiated chemically induced epithelial skin tumors. Once it has been demonstrated that diet-derived flavonoids are able to affect the pattern of tumor cell differentiation (Orsolic et al., 2005), the data obtained in this investigation might be indirectly related to the flavonoids content verified in the extract. Supporting such theory, it has been previously reported that flavonoids can stimulate terminal differentiation in lymphocytes-derived tumor cells lines (Constantinou et al., 1990). The biochemical and molecular mechanisms underlying such biomodulatory effects on the tumor cell differentiation are not completely clarified, but it has been suggested that it is likely associated to the stimulation of apoptosis pathways (Lowe \& Lin, 2000). In addition, ethanolic propolis extract was shown to markedly augment Tumor necrosis factor related apoptosis inducing ligand (TRAIL) mediated apoptosis in HeLa cancer cells (TRAILinduced apoptosis resistant cells) (Szliszka et al.). Nevertheless, further research is necessary in order to clarify the precise pathogenesis of cell differentiation stimuli induced by propolis extract.

An important histological finding observed in this study was the significant decrease in the frequency of muscle invasion and formation of lymphatic vessels emboli in HEGP-treated groups. The mechanism underlying this biological effect still remains unclear. It has been demonstrated that chemical compounds present in HEGP, such as artepillin C and CAPE, are able to selectively block the PAK1 gene (Messerli et al.). It is well-established that PAK1 is a kinase protein closely related to angiogenesis and motility of tumor cells (Kiosses et al., 2002). Therefore, blocking of PAK1 might reduce the motility of tumor cells and consequently inhibit the invasion of lymphatic vessels. In addition, the inhibition of angiogenesis would reduce the vascular component, minimizing the risk of lymphohematogenic formation of tumor emboli and metastasis. Supporting this theory, Ahn et al., (2007) demonstrated that administration of HEGP-derived artepillin $\mathrm{C}$ promoted antitumor effect as a result of angiogenesis blocking. In addition, it has been previously reported that flavonoids are able to suppress the metalloproteinasis release, enzymes extensively used by tumor cells to degrade the extracellular matrix (Kanadaswami et al., 2005). Therefore, such chemical compounds might inhibit tumor cells migration, which could justify the lower invasiveness of the HEGPtreated groups.

It has been shown that polar compounds found in propolis, such as flavonoids, are able to modulate the inflammatory response by stimulating macrophages, augmenting the phagocytosis activity, as well as enhancing 
PEREIRA-FILHO, R. N.; BATISTA, F. S.; RIBEIRO, D. R.; MELO, G. C.; REIS, F. P.; MELO, A. U. C.; GOMES, M. Z.; CARDOSO, J. C. \& ALBUQUERQUE-JÚNIOR, R. L. C Chemopreventive effect of Brazilian green propolis on experimental dermal carcinogenesis in murine model. Int. J. Morphol., 32(2):522-530, 2014.

the release of cytokines, such as tumor necrosis factor alpha (TNF-a), and reactive oxygen species (Fischer et al., 2008). In addition, Fischer et al. (2007) also demonstrated that HEGP promotes increase of mRNA expression of interferon gama (IFN-g), a cytokine closely related to the positive regulation of cell-mediated immune response.

However, no difference was observed in the magnitude of the inflammatory response between groups, regardless the treatment with HEGP. These findings suggest that the nature and intensity of the immune response against the epithelial tumors was not influenced by the chemical compounds of the propolis extract. A wide range of different factors might have determined these results, such variation in the immunogenicity of tumor cells, and variability in the concentration of the diverse flavonoids and other phenolic compounds.
In conclusion, we demonstrated that oral administration of HEGP exerts chemopreventive effects on chemical skin carcinogenesis, partially inhibiting the raise of DMBA-induced cutaneous tumors, as well as appeared to modulate the tumor differentiation and infiltrative potential in murine model. Notwithstanding the relevance of such experimental findings, further studies are still required in order to unveil the mechanisms underlying the chemopreventive role played by Brazilian green propolis.

\section{ACKNOWLEDGEMENTS}

We would like to thank the Foundation for Research and Technological Innovation Support from Sergipe, Brazil (FAPITEC/SE) for the financial support.

PEREIRA-FILHO, R. N.; BATISTA, F. S.; RIBEIRO, D. R.; MELO, G. C.; REIS, F. P.; MELO, A. U. C.; GOMES, M. Z.; CARDOSO, J. C. \& ALBUQUERQUE-JÚNIOR, R. L. C. Efecto quimiopreventivo del propóleos verde brasileño sobre la carcinogénesis cutánea en el modelo murino experimental. Int. J. Morphol., 32(2):522-530, 2014.

RESUMEN: El objetivo de este estudio fue evaluar el efecto de la administración oral de extracto hidroalcohólico del propóleos verde (HEGP) sobre la carcinogénesis dérmica en modelo de roedores. Para el ensayo biológico, se utilizaron 36 ratones asignados en 6 grupos ( $\mathrm{n}=6$ ): CTR (tratado con $100 \mathrm{mg} / \mathrm{kg}$ HEGP y sin inducción de tumores), TUM (tratada con agua e inducción de tumores), GP10 (tratado con $10 \mathrm{mg} / \mathrm{kg}$ HEGP e inducción de tumores), GP50 (tratado con $50 \mathrm{mg} / \mathrm{kg}$ HEGP e inducción de tumores) y GP100 (tratado con $100 \mathrm{mg} / \mathrm{kg}$ HEGP e inducción de tumores). La inducción de cáncer se llevó a cabo en la región dorsal de los ratones por aplicación tópica de DMBA. Después de 16 semanas, los ratones fueron sacrificados y sus dorsos fueron sometidos a análisis histológico post-mortem. El número medio de lesiones desarrolladas en TUM $(4,14 \pm 0,89)$ fue significativamente mayor que GP10 $(2,05 \pm 1,02)$, GP50 $(1,8 \pm 1,92)$ y gp100 $(2,5 \pm 1,73)(\mathrm{p}<0,05)$. Los tumores formados en grupos tratados con HEGP fueron histológicamente más diferenciados, pero sólo en PV100 las lesiones in situ fueron manifiestas. La infiltración de las estructuras anatómicas blanco fue menos frecuente en los grupos tratados con HEGP $(\mathrm{p}<0,05)$. Nuestros datos sugieren que la administración oral de HEGP proporciona una inhibición parcial de la carcinogénesis dérmica inducida por DMBA, así como pareció modular la diferenciación y potencial infiltrante de los carcinomas en el modelo animal.

PALABRAS ClAVE: DMBA; Propoleos; Cáncer de piel.

\section{REFERENCES}

Ahn, M. R.; Kunimasa, K.; Ohta, T.; Kumazawa, S.; Kamihira, M.; Kaji, K.; Uto, Y.; Hori, H.; Nagasawa, H. \& Nakayama, T. Suppression of tumor-induced angiogenesis by Brazilian propolis: major component artepillin $\mathrm{C}$ inhibits in vitro tube formation and endothelial cell proliferation. Cancer Lett., 252(2):235-43, 2007

Araújo, M. J. A. M.; Dutra, R. P.; Costa, G. C.; Reis, A. S.; Assunção, A. K. M. \& Libério, S. A.; Maciel, M. C. G.; Silva, L. A.; Guerra, R. N. M.; Ribeiro, M. N. S. \& Nascimento, F. R. F. Efeito do tratamento com própolis de Scaptotrigona aff. postica sobre o desenvolvimento do tumor de Ehrlich em camundongos. Rev. Bras. Farmacogn., 20(4):580-7, 2010.
Araujo, M. A. R.; Libério, S. A.; Guerra, R. N. M.; Ribeiro, M. N. S. \& Nascimento, F. R. F. Mechanisms of action underlying the anti-inflammatory and immunomodulatory effects of propolis: a brief review. Braz. J. Pharmacogn., 22(1):208-19, 2012.

Bonerandi, J. J.; Beauvillain, C.; Caquant, L.; Chassagne, J. F.; Chaussade, V.; Clavère, P.; Desouches, C.; Garnier, F.; Grolleau, J. L.; Grossin, M.; Jourdain, A.; Lemonnier, J. Y.; Maillard, H.; Ortonne, N.; Rio, E.; Simon, E.; Sei, J. F.; Grob. J. J.; Martin, L. $\&$ French Dermatology Recommendations Association (aRED). Guidelines for the diagnosis and treatment of cutaneous squamous cell carcinoma and precursor lesions. J. Eur. Acad. Dermatol. Venereol., 25 Suppl. 5:1-51. 2011. 
PEREIRA-FILHO, R. N.; BATISTA, F. S.; RIBEIRO, D. R.; MELO, G. C.; REIS, F. P.; MELO, A. U. C.; GOMES, M. Z.; CARDOSO, J. C. \& ALBUQUERQUE-JÚNIOR, R. L. C. Chemopreventive effect of Brazilian green propolis on experimental dermal carcinogenesis in murine model. Int. J. Morphol., 32(2):522-530, 2014.

Cavalcante, D. R.; Oliveira, P. S.; Góis, S. M.; Soares, A. F.; Cardoso, J. C.; Padilha, F. F. \& Albuquerque Jr., R. L. Effect of green propolis on oral epithelial dysplasia in rats. Braz. J. Otorhinolaryngol., 77(3):278-84, 2011.

Constantinou, A.; Kiguchi, K. \& Huberman, E. Induction of differentiation and DNA strand breakage in human HL-60 and K-562 leukemia cells by genistein. Cancer Res., 50(9):261824, 1990.

Cragg, G. M.; Grothaus, P. G. \& Newman, D. J. Impact of natural products on developing new anti-cancer agents. Chem. Rev., 109(7):3012-43, 2009.

Fischer, G.; Conceição, F. R.; Leite, F. P.; Dummer, L. A.; Vargas, G. D.; Hübner Sde, O.; Dellagostin, O. A.; Paulino, N.; Paulino, A. S. \& Vidor, T. Immunomodulation produced by a green propolis extract on humoral and cellular responses of mice immunized with SuHV-1. Vaccine, 25(7):1250-6, 2007.

Fischer, G.; Hübner Sde, O.; Vargas, G. D. \& Vidor, T. Imunomodulação pela própolis. Arq. Inst. Biol., 75(2):247-53, 2008.

Franchi, G. C. Jr.; Moraes, C. S.; Toreti, V. C.; Daugsch, A.; Nowill, A. E. \& Park, Y. K. Comparison of effects of the ethanolic extracts of brazilian propolis on human leukemic cells as assessed with the MTT assay. Evid. Based Complement Alternat. Med., 2012:918956, 2012.

Kandaswami, C.; Lee, L. T.; Lee, P. P.; Hwang, J. J.; Ke, F. C.; Huang, Y. T. \& Lee, M. T. The antitumor activities of flavonoids. In Vivo, 19(5):895-909, 2005.

Kavitha, K. \& Manoharan, S. Anticarcinogenic and antilipidperoxidative effects of Tephrosia purpurea (Linn.) Pers. in 7, 12-dimethylbenz(a)anthracene (DMBA) induced hamster buccal pouch carcinoma. Indian J. Pharmacol., 38(3):185-9, 2006.

Kim, R. H. \& Armstrong, A. W. Nonmelanoma skin cancer. Dermatol. Clin., 30(1):125-39, 2012.

Kiosses, W. B.; Hood, J.; Yang, S.; Gerritsen, M. E.; Cheresh, D. A.; Alderson, N. \& Schwartz, M. A. A dominant-negative p65 PAK peptide inhibits angiogenesis. Circ. Res., 90(6):697-702, 2002.

Kunimasa, K.; Ahn, M. R.; Kobayashi, T.; Eguchi, R.; Kumazawa, S.; Fujimori, Y.; Nakano, T.; Nakayama, T.; Kaji, K. \& Ohta, T. Brazilian Propolis Suppresses Angiogenesis by Inducing Apoptosis in Tube-Forming Endothelial Cells through Inactivation of Survival Signal ERK1/2. Evid. Based Complement. Alternat. Med., 2011:870753, 20110.

Lowe, S. W. \& Lin, A. W. Apoptosis in cancer. Carcinogenesis, 21(3):485-95, 2000
Messerli, S. M.; Ahn, M. R.; Kunimasa, K.; Yanagihara, M.; Tatefuji, T.; Hashimoto, K.; Mautner, V.; Uto, Y.; Hori, H.; Kumazawa, S.; Kaji, K.; Ohta, T. \& Maruta, H. Artepillin C (ARC) in Brazilian green propolis selectively blocks oncogenic PAK1 signaling and suppresses the growth of NF tumors in mice. Phytother. Res., 23(3):423-7, 2009.

Orsolic, N.; Terzic, S.; Mihaljevic, Z.; Sver, L. \& Basic, I. Effects of local administration of propolis and its polyphenolic compounds on tumor formation and growth. Biol. Pharm. Bull., 28(10):1928-33, 2005.

Orsolic, N.; Saranovic, A. B. \& Basic, I. Direct and indirect mechanism(s) of antitumour activity of propolis and its polyphenolic compounds. Planta Med., 72(1):20-7, 2006.

Ozi, J. M.; Suffredini, I. B.; Paciencia, M.; Frana, S. A. \& Dib, L. L. In vitro cytotoxic effects of Brazilian plant extracts on squamous cell carcinoma of the oral cavity. Braz. Oral Res., 25(6):519-25, 2011.

Sawaya, A. C.; Barbosa Da Silva Cunha, I. \& Marcucci, M. C. Analytical methods applied to diverse types of Brazilian propolis. Chem. Cent. J., 5(1):27, 2011.

Szliszka, E.; Czuba, Z. P.; Domino, M.; Mazur, B.; Zydowicz, G. \& Krol. W. Ethanolic extract of propolis (EEP) enhances the apoptosis- inducing potential of TRAIL in cancer cells. Molecules, 14(2):738-54, 2009.

Wu, J.; Omene, C.; Karkoszka, J.; Bosland, M.; Eckard, J.; Klein, C. B. \& Frenkel, K. Caffeic acid phenethyl ester (CAPE), derived from a honeybee product propolis, exhibits a diversity of anti-tumor effects in pre-clinical models of human breast cancer. Cancer Lett., 308(1):43-53, 2011.

Yanofsky, V. R.; Mercer, S. E. \& Phelps, R. G. Histopathological variants of cutaneous squamous cell carcinoma: a review. $J$. Skin Cancer, 2011:210813, 2011.

Correspondence to:

Dr. Ricardo Luiz Cavalcanti de Albuquerque Junior

Oral Pathologist, School of Dentistry

University Tiradentes

Aracaju/SE, 49032-490

BRAZIL

E-mail: ricardo.patologia@uol.com.br

Received: 15-03-2013

Accepted: 10-02-2014 